\title{
Anti-Asthmatic Effects of Portulaca Oleracea and its Constituents, a Review
}

\author{
Mohammad Reza Khazdair ${ }^{1}$, Akbar Anaeigoudari², Majid Kianmehr ${ }^{3 *}$ \\ ${ }^{1}$ Torbat Jam Faculty of Medical Sciences, Torbat Jam, Iran \\ ${ }^{2}$ Department of Physiology, School of Medicine, Jiroft University of Medical Sciences, Jiroft, Iran \\ ${ }^{3}$ Esfarayen Faculty of Medical sciences, Esfarayen, Iran
}

\section{Key Words}

Portulaca oleracea, Quercetin, smooth muscle, anti-inflammatory effects, antioxidant effects, relaxant effects

\begin{abstract}
Objectives: The medicinal plants are believed to enhance the natural resistance of the body to infections. Some of the main constituents of the plant and derived materials such as, proteins, lectins and polysaccharides have anti-inflammatory effects. Portulaca oleracea (P. oleracea) were used traditionally for dietary, food additive, spice and various medicinal purposes. This review article is focus on the anti-asthmatic effects of P. oleracea and its constituents.
\end{abstract}

Methods: Various databases, such as the PubMed, Scopus, and Google Scholar, were searched the keywords including "Portulaca oleracea", "Quercetin", "Anti-inflammatory", "Antioxidant", "Cytokines", "Smooth muscle ", and " Relaxant effects " until the end of Jul 2018.

Results: P. oleracea extracts and its constituents increased IFN- $\gamma$, IL-2, IFN $\gamma /$ IL- 4 and IL- 10/IL-4 ratio, but decreased secretion of TNF- $\alpha$, IL- 4 and chemokines in both in vitro and in vivo studies. P. oleracea extracts and quercetin also significantly decreased production of NO,

Received: Sep 08, 2018 Reviewed: Mar 11, 2019 Accepted: May 27, 2019

(c) This is an Open-Access article distributed under the terms of the Creative Common Attribution Non-Commercial License (http://creativecommons.org/licenses/by-nc/4.0/) which permits unrestricted noncommercial use, distribution, and reproduction in any medium, provided the original work is properly cited.

(1) This paper meets the requirements of KS X ISO 9706, ISO 9706-1994 and ANSI/NISO Z39.48-1992 (Permanence of Paper). stimulated $\beta$-adrenoceptor and/or blocking muscarinic receptors in tracheal smooth muscles. Conclusion: P. oleracea extracts and quercetin showed relatively potent anti-asthmatic effects due to decreased production of NO, inflammatory cytokines and chemokines, reduced oxidant while enhanced antioxidant markers, and also showed potent relaxant effects on tracheal smooth muscles via stimulatory on $\beta$-adrenoceptor or/and blocking muscarinic receptors.

\section{Introduction}

Asthma is a complex inflammatory disorder which characterized by airway inflammation and hyper-responsiveness, hyper-secretion of mucus by goblet cells and eosinophilic inflammation [1]. Asthma is triggered by a very complex interaction between high serum levels of immunoglobulin E (IgE) and production of inflammatory mediators such as; interleukin (IL)-4, IL-5, and IL-13 by T-helper 2 (Th2) cells [2]. Asthma disease could be as a result of airway inflammation [3] and smooth muscle dysfunction [4]. Corticosteroids inhibiting eosinophil function and bronchodilator drugs contribute to the treatment of asthma $[5,6]$. It has been reported that combination therapy with corticosteroids and $\bigotimes$-agonists reduced tracheal hyper-responsiveness and lung inflammation in ovalbumin sensitized animal model $[7,8]$.

Medicinal plants used in traditional medicine have been revealed to treatment of various inflammatory disorders such as asthma. The medicinal plants used for asthma should have anti- inflammatory, antihista-

"Corresponding Author

VMajid Kianmehr. Esfarayen Faculty of Medical sciences, Esfarayen, Iran majid.kianmehr@gmail.com 
minic, immunomodulatory and smooth-muscle relaxants activity[9]. Portulaca oleracea (P. oleracea) or Purslane belongs to the Portulacaceae family (Fig. 1). This plant is an annual and grassy plant with small-yellow flowers, which grows in different areas of the world including; Southern Europe, Indies, China, Japan, north and north-west of Iran [10].

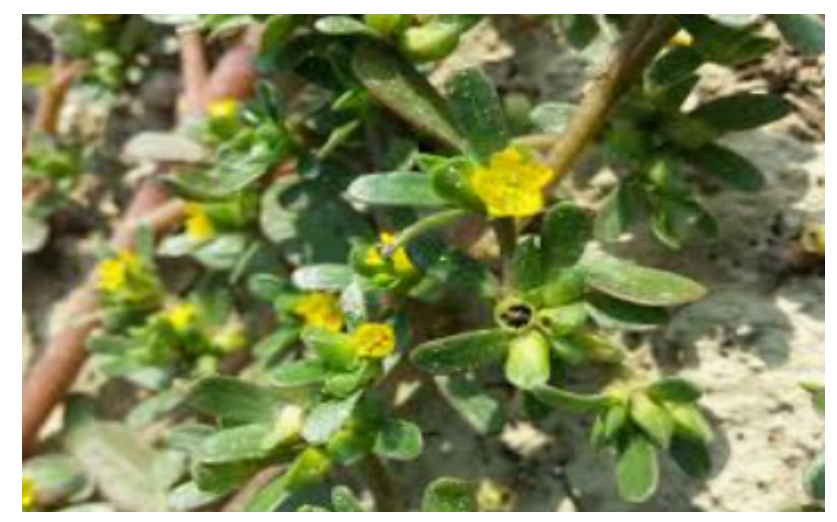

Figure 1 Leaf and flowers of Portulaca oleracea

P. oleracea has several pharmacological effects including; neuroprotective [11], hepatoprotective [12], antioxidant [13], anti-inflammatory [14] and immunomodulatory effects [15]. In this review, we reviewed the anti-asthmatic properties of P. oleracea with several mechanisms such as anti-inflammatory, smooth muscle relaxant and antioxidant effects.

\section{Methods}

The databases such as, PubMed, Scopus and Google Scholar were considered for searching until the end of Jul 2018. The search terms "Portulaca oleracea", "Quercetin", "Anti- inflammatory", "Cytokines", "Smooth muscle ", " Relaxant effects" and "antioxidant" were used. All studies such as, in vitro studies, animal studies, review articles and clinical studies were included. Letter to Editor and unpublished data were the exclusion criteria.

\section{Constituents of P.oleracea}

P. oleracea or Purslane contains omega-3 fatty acids and alpha-linolenic acid more than

other leafy vegetable plant [16]. It also has $0.01 \mathrm{mg} / \mathrm{g}$ of eicosa- pentaenoic acid (EPA). EPA is an Omega-3 fatty acid found mostly in fish and some algae. Purslane contains vitamins as well as nutritive minerals such as iron, magnesium, potassium, and calcium. Purslane also contains potent antioxidants and anti-mutagenic agents including betalain alkaloid pigments and the yellow betaxanthins [17] as well as flavonoids (kaempferol, apigenin, myricetin, portulacanones $\mathrm{A}, \mathrm{B}, \mathrm{C}$ and $\mathrm{D}$ ), alkaloids (opleraceins A, B, C, D and E), fatty acids, terpenoids (portuloside A and $B$ ), polysaccharides, and vitamins [18].

\section{Anti-inflammatory and antioxidant effects}

\subsection{P.oleracea}

The hydro-ethanolic extracts $(10,40$ and $160 \mu \mathrm{g} / \mathrm{ml})$ of P. oleracea significantly increased IFN- $\gamma$, IFN- $\gamma / \mathrm{IL}-4$ ratio and IL-10/IL-4 ratios in non-stimulated and stimulated human lymphocytes cells. In stimulated lymphocytes, the extract of P. oleracea significantly decreased inflammatory cytokines such as, IL-4, IL-10 and free radicals such as nitric oxide (NO). In addition administration of P. oleracea extract significantly increased IFN- $\gamma /$ IL- 4 and IL-10/IL-4 [19]. The aqueous extracts of P. oleracea (10, 25, 50 and 100 $\mu \mathrm{g} / \mathrm{ml}$ ) in a dose- dependent manner significantly inhibited TNF- $\alpha$-induced intracellular reactive oxygen species (ROS) production. P. oleracea also suppressed the TNF- $\alpha$ induced degradation of $\mathrm{I} x \mathrm{~B}-\alpha$ and reduced the TNF- $\alpha$-induced NF- $x$ B binding protein in the vascular endothelial cells. The plant extracts in a dose-dependent manner also effectively reduced mRNA expression of Monocyte chemoattractant protein-1 (MCP-1) and IL- 8 caused by TNF- $\alpha$ [20]. The ethanol extract of P. oleracea $(50,100$ and $200 \mu \mathrm{g} /$ $\mathrm{ml}$ ) inhibited production of inflammatory mediators such as NO and pro-inflammatory cytokines including; TNF- $\alpha$, IL-1 $\beta$ and IL-6 in LPS-induced inflammation in RAW 264.7 cells (derived from BALB/c mice). In addition, P. oleracea extract inhibited the phosphorylation of (ERK1/2), c-Jun NH2-terminal kinase (JNK) and NF- $\varkappa$ B activation in cells [21]. POL-P3b as a polysaccharide fraction purified from P. oleracea) $(250 \mu \mathrm{g} / \mathrm{ml})$ up-regulated the expression of CD80, CD86, CD83, and stimulated production of more IL-12, TNF- $\alpha$, and less IL-10 on the maturation and function of murine bone-marrow- derived dendritic cells (DCs). Moreover, POL-P3b significantly increased the expression of Toll-like receptor 4 (TLR-4) on DCs treated. These results suggested that POL-P3b may induce DCs maturation through TLR-4 [22]. The orally administration of P. oleracea polysaccharides $(100,200,300,400,500$ and $600 \mu \mathrm{g} / \mathrm{ml}$ ) significantly increased stimulation indices (SI) of T lymphocytes and B lymphocytes dose-dependently in Wistar rats [23]. The polysaccharide (POP) from P. oleracea showed preventive effect on reduction of the spleen weight and the number of murine spleen T cells after 30 days of inducing age in the mice with D-galactose [24].

Besides anti-inflammatory effect, P. oleracea has been shown to have antioxidant effects [25]. It has been reported that P. oleracea improves oxidative stress in vitamin A deficient rats [26]. Researchers also documented that hydro-ethanolic extract of P. oleracea decreased the serum level of oxidant agents such as NO2, NO3 and malondialdehyde (MDA) and enhanced the serum level of antioxidant parameters such as superoxide dismutase (SOD) and catalase (CAT) in sensitized rats. It has been indicated that this effect of P. oleracea is comparable with effect of dexamethasone [27]. In addition, it has been documented that pretreatment with extract of P. oleracea ameliorated oxidative stress in streptozotocin- induced diabetic rats via reducing MDA concentration and enhancing the level of glutathione (GSH). In another study, ethanol extract of P. oleracea has been shown to protect the lungs of mice exposed to hypoxia due to its antioxidant effects [28]. The ethanol extract of P. oleracea reduced ROS and MDA level in the lung tissue and enhanced the level of GSH and SOD 
when it was orally $(100,200$ and $400 \mathrm{mg} / \mathrm{kg})$ injected [29]. In addition, P. oleracea has been reported to a significant increase in level of glutathione peroxidase (GPx), glutathione-S- transferase (GST) and glutathione reeducates (GR) in hepatic and renal tissues of rats [30].

\subsection{Quercetin}<smiles>O=c1c(O)c(-c2ccc(O)c(O)c2)oc2cc(O)cc(O)c12</smiles>

Figure 2 Quercetin

Quercetin (a natural flavonoid found in many vegetables and fruits including P. oleracea), dose dependently inhibited TNF- $\alpha$ production and attenuated the cytokines and chemokines production by LPS-stimulated DCs. The quercetin $(6.25,12.5,50$ and $100 \mu \mathrm{g} / \mathrm{ml})$ treatment significantly decreased the generation of inflammatory cytokines such as IL-1 $\alpha$, IL-1 $\beta$, IL-6, and IL-12 and chemokines such as MCP-1, MIP-1a, MIP-1b in LPS-stimulated DCs. Quercetin administration also significantly reduced the levels of CD40, CD80, and CD86 in DCs stimulated by LPS. Quercetin also down regulated the cytokines and chemokines secreted by activated DCs [31]. Quercetin $(40 \mu \mathrm{M})$ suppressed gene transcription of IL-2 and IFN- $\gamma$ cytokines while it could not attenuate IL-4 transcript. Quercetin has been shown to inhibit the increased expression of IL-2Ra in response to exogenous recombinant human IL-2 and TCR stimulation [32].

Quercetin $(1,10,50 \mu \mathrm{M})$ inhibited the iNOS, TNF- $\square$ and IL-1 $\beta$ expression and IkB- $\alpha$ phosphorylation induced by LPS in bone marrow-derived macrophages (BMDM). In addition quercetin treatment $(1 \mathrm{mg} / \mathrm{kg} /$ day, p.o.) in vivo, inhibited TNF- $\alpha$, IL- $1 \beta$ and iNOS, expression induced by dextran sulfate sodium (DSS) in rats [33].

The level of eosinophils were significantly reduced $68.79 \%$ and $73.35 \%$ by quercetin ( 8 and $16 \mathrm{mg} / \mathrm{kg} /$ day, i.p, respectively) in Bronchoalveolar lavage fluid (BALF) of mice airway challenge with ovalbumin (OVA). Quercetin also reduced the concentration of IL-4, IL-5, and mRNA expression of matrix metallopeptidase-9 (MMP-9) and increased the concentration of IFN- $\gamma$ in the BALF as compared to OVA-sensitized mice [34]. Anti-inflammatory effects of P. oleracea and quercetin were showed in the Table 1.

\subsection{Alpha Linolenic Acid}

Alpha linolenic acid (ALA) is considered as one of the main constituent of P. oleracea [35]. This omega-3 fatty acid has been reported to modulate the immune system function through affecting T lymphocytes [36]. It has been documented that ALA can enhance the level of eicosapentaenoic acid in the cell membrane as well as reduction of pro-inflammatory cytokines including IL-1 and TNF- $\bigotimes$. These changes were associated with a reduction response to allergens in asthma [37]. Scientific evidence have also been indicated that treatment of sensitized rats with two concentration of ALA $(0.2$ and $0.4 \mathrm{mg} / \mathrm{kg})$ resulted in a decrease in NO2, NO3 and MDA concentration and an increase in the serum level of thiol, SOD and CAT [27]. These reports confirm the anti-inflammatory and antioxidant of ALA.<smiles>CC/C=C\C/C=C\C/C=C\CCCCCCCC(=O)O</smiles>

Figure 3 Alpha Linolenic Acid

\subsection{Other constituents}

Besides Flavonoids such as quercetin and fatty acids including ALA, P. oleracea possesses other several constituents such as alkaloids, terpenoids, vitamins, sterols, proteins and minerals [18]. Alkaloids presence such as dopa, dopamine and noradrenalin in leaves of P. oleracea has been confirmed [38]. Monoterpenes including portulosides $A$ and $B$, as well as diterpens have been reported in extract of P. oleracea [39]. In addition, P. oleracea is a rich source of vitamins such as vitamin $A$, ascorbic acid and B- complex vitamins. Vitamin A and ascorbic acid are natural antioxidant found in P. oleracea [18, 40]. P. oleracea also contains several minerals including manganese, calcium and phosphorus as well as amino acids like proline, leucine, isoleucine, lysine, cysteine and tyrosine [41]. 
Table 1 Anti-inflammatory and antioxidant effects of P. oleracea and its constituents

\begin{tabular}{|c|c|c|c|c|c|}
\hline Plants & Extract & $\begin{array}{l}\text { Effective } \\
\text { doses }\end{array}$ & $\begin{array}{l}\text { Model of } \\
\text { study }\end{array}$ & Effects & Ref. \\
\hline \multirow[t]{8}{*}{ P.oleracea } & Hydro-ethanolic & $160 \mu \mathrm{g} / \mathrm{ml}$ & Lymphocyte & $\begin{array}{l}\text { Increased IL-4, IL-10, IFN- } \gamma \text {, } \\
\text { IFN- } \gamma / \text { IL-4 and IL-10/IL-4 ratios }\end{array}$ & [19] \\
\hline & Aqueous extract & $100 \mu \mathrm{g} / \mathrm{ml}$ & $\begin{array}{l}\text { Vascular } \\
\text { endothelial } \\
\text { cells }\end{array}$ & $\begin{array}{l}\text { Decreased mRNA expressions } \\
\text { of MCP-1 and IL- } 8\end{array}$ & {$[20]$} \\
\hline & Ethanol & $200 \mu \mathrm{g} / \mathrm{ml}$ & $\begin{array}{l}\text { RAW } 264.7 \\
\text { cells }\end{array}$ & $\begin{array}{l}\text { Decreased TNF- } \alpha, \text { IL- } 1 \beta \text { and IL- } \\
6\end{array}$ & {$[21]$} \\
\hline & POL-P3b & $\begin{array}{l}(250 \\
\mu \mathrm{g} / \mathrm{ml})\end{array}$ & DCs & Increased IL-12, and IL-10 & {$[22]$} \\
\hline & polysaccharide & $\begin{array}{l}600 \mu \mathrm{g} / \mathrm{ml}, \\
\text { p.o. }\end{array}$ & Rat & $\begin{array}{l}\text { Increased T lymphocytes and B } \\
\text { lymphocytes }\end{array}$ & {$[23]$} \\
\hline & Hydro-ethanolic & $\begin{array}{l}1,2 \text { and } 4 \\
\mathrm{mg} / \mathrm{mL} \\
\text { p.o. }\end{array}$ & Rats & $\begin{array}{l}\text { Decreased the serum level of } \\
\text { NO2, NO3 and (MDA) and } \\
\text { enhanced the serum level of } \\
\text { SOD and CAT }\end{array}$ & {$[27]$} \\
\hline & Ethanol & $\begin{array}{l}100 \text { and } \\
250 \mathrm{mg} / \mathrm{kg}\end{array}$ & Mice & $\begin{array}{l}\text { Shown antioxidant effects on } \\
\text { the lungs }\end{array}$ & {$[28]$} \\
\hline & Ethanol & $\begin{array}{l}100,200, \\
\text { and } \\
400 \mathrm{mg} / \mathrm{kg}\end{array}$ & Mice & $\begin{array}{l}\text { Reduced ROS and MDA } \\
\text { level in the lung tissue and } \\
\text { enhanced the level of GSH } \\
\text { and SOD }\end{array}$ & [29] \\
\hline \multirow[t]{9}{*}{$\begin{array}{l}\text { Component of } \\
\text { P.oleracea }\end{array}$} & \multirow[t]{7}{*}{ Quercetin } & $100 \mu \mathrm{g} / \mathrm{ml}$ & DCs & $\begin{array}{l}\text { Decreased IL-1 } \alpha, \text { IL-1 } \beta, \text { IL-6, } \\
\text { IL-10, IL-12 p70) and MCP-1, } \\
\text { MIP-1 a , MIP-1 b }\end{array}$ & {$[31]$} \\
\hline & & $40 \mu \mathrm{M}$ & Th cells & $\begin{array}{l}\text { Decreased IL-2, IFN- } \gamma \text { and IL- } \\
\text { 2Ra expression }\end{array}$ & {$[32]$} \\
\hline & & $50 \mu \mathrm{M}$ & PBMC & $\begin{array}{l}\text { Decreased IL-4 } \\
\text { Increased IFN- } \gamma\end{array}$ & {$[42]$} \\
\hline & & $\begin{array}{ll}50 \\
\mu \mathrm{M}+\mathrm{IFN}-\beta\end{array}$ & PBMC & $\begin{array}{l}\text { Decreased IL-1 } \beta, \text { TNF- } \alpha \text {, } \\
\text { MMP-9, and TIMP-1 }\end{array}$ & {$[43]$} \\
\hline & & $50 \mu \mathrm{M}$ & BMDM & $\begin{array}{l}\text { Decreasedexpression of iNOS, } \\
\text { TNF- } \alpha, \text { IL- } 1 \beta \text { and } I_{k} B- \\
\alpha \text { phosphorylation }\end{array}$ & {$[33]$} \\
\hline & & $\begin{array}{l}1 \\
\mathrm{mg} / \mathrm{kg} / \mathrm{day}, \\
\text { p.o. }\end{array}$ & Rat & $\begin{array}{l}\text { Decreased TNF- } \alpha, \text { IL-1 } \beta \\
\text { expression and iNOS }\end{array}$ & {$[33]$} \\
\hline & & $\begin{array}{l}1500 \\
\mathrm{mg} / \text { day, } \\
\text { p.o. }\end{array}$ & Human & $\begin{array}{l}\text { Decreased IL-6, ICAM-1 } \\
\text { Increased IL-10 }\end{array}$ & {$[44]$} \\
\hline & \multirow[t]{2}{*}{$\begin{array}{l}\text { Alpha } \\
\text { Linolenic } \\
\text { Acid }\end{array}$} & $\begin{array}{l}0.2 \text { and } 0.4 \\
\mathrm{mg} / \mathrm{ml}\end{array}$ & Rats & $\begin{array}{l}\text { Significantly decreased } \\
\text { BALF levels of TP, PLA2, } \\
\text { IgE and IL-4 }\end{array}$ & {$[37]$} \\
\hline & & $\begin{array}{l}0.2 \text { and } \\
0.4 \mathrm{mg} / \mathrm{kg}\end{array}$ & Rats & $\begin{array}{l}\text { Decreased NO2, NO3 and } \\
\text { MDA concentration and an } \\
\text { increase in the serum level of } \\
\text { thiol, SOD and CAT }\end{array}$ & {$[27]$} \\
\hline
\end{tabular}

IL: interleukin, IFN- $\gamma$ : Interferon Gama, POL-P3b: polysaccharide fraction, MCP-1: Monocyte chemoattractant protein-1, TNF- $\alpha$ : Tumor necrosis factor- $\alpha$, NO: Nitrogen oxide, MDA: malondialdehyde, SOD: superoxide dismutase, CAT: catalase, MIP: Macrophage Inflammatory Proteins, MMP-9: Matrix Metalloprotienase-9, TIMP-1: Tissue inhibitors of metalloproteinases-1, iNOS: Inducible nitric oxide synthase, ICAM-1: Intercellular Adhesion Molecule 1. BALF: bronchoalveolar lavage fluid, TP: total protein, PLA2: phospholipase A2, IgE: immunoglobulin E. 


\section{Smooth muscle relaxant effects}

\subsection{P. oleracea}

The relaxant effect of P. oleracea on skeletal muscle [45] and smooth muscle [46] has been shown. In asthmatic patients, bronchodilatory effect of boiled extract of P.oleracea was evaluated. The results showed that boiled extract of P. oleracea significantly enhanced all measured pulmonary function tests (PFTs). It has been reported that this bronchodilatory effect is similar to theophylline syrup [46]. Aqueous extract of P. oleracea reduced pristaltic index by antagonistic effects on calcium channel in the isolated guinea pig ileum strip [47].

The Aqueous extract of the plant also showed relaxant effect on smooth muscle and reduced blood pressure in guinea pig fundus, rabbit jejunum and rabbit aorta [48]. The hydro-ethanolic extract of P. oleracea $(0.06,0.12$ and $0.25 \mathrm{mg} / \mathrm{ml}$ ) in dose depend manner showed a stimulatory effect on $\beta$-adrenoceptor in tracheal smooth muscles of guinea pigs [49]. The relaxant effect of P. oleracea on tracheal smooth muscles via blocking of muscarinic receptor was also investigated [50]. The researchers suggested that bronchodilatory effects of P. oleracea can attribute to stimulation of $\beta 2$ adronceptors [51], stimulation of inhibitory non- adrenergic and non-cholinergic nervous system [46], opening potassium channels [52], inhibition of phosphodiestrase [53] and calcium antagonism [54]. Ethyl acetate (EA) of P. oleracea extract has been indicated to decrease intestinal motility in ICR mice receiving this fraction compared to those of treated with acetylcholine [55]. Based on the results of scientific studies, the aqueous extract of P. oleracea has been shown to ameliorate impairment of acetylcholine (Ach)- and sodium nitroprusside (SNP) induced vascular relaxant of aortic rings in diabetic $\mathrm{db} / \mathrm{db}$ mice, which this improving effect is as-

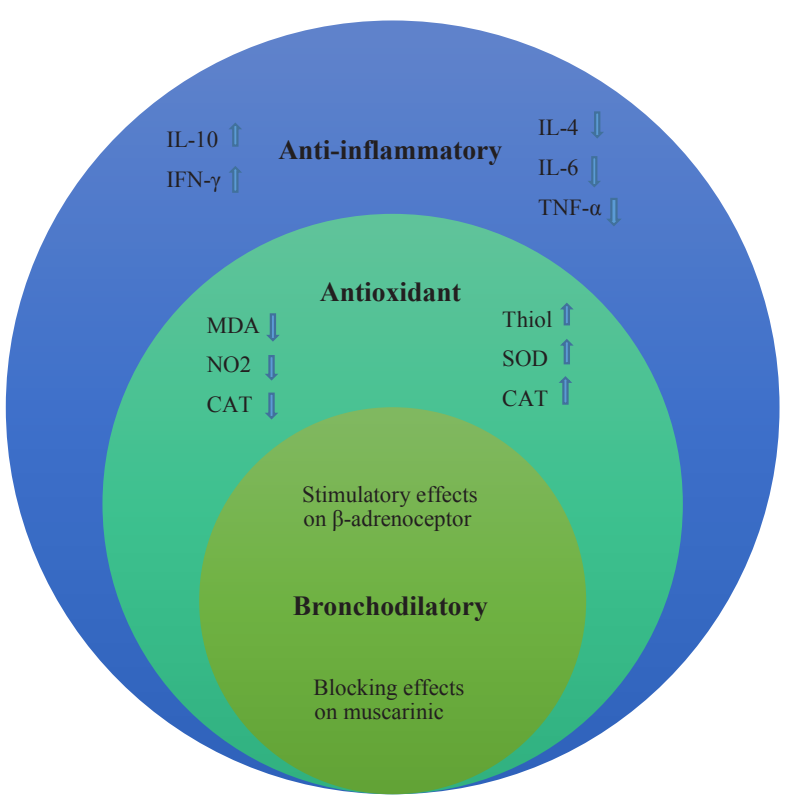

Figure 4 The mechanism of pharmacological action of P. oleracea. sociated with a significant decrease in the level of vasoconstrictor endothelin (ET) -1. It has also been suggested that the aqueous extract of P. oleracea suppresses overexpression of vascular cell adhesion molecule (VCAM) -1, intracellular cell adhesion molecular (ICAM) - 1, E- selectin and matrix metalloproteinase (MMP) -2 in aortic tissue in $\mathrm{db} / \mathrm{db}$ mice [56].

Extracted quercetin from P.oleracea has been proposed to have relaxant effect on smooth muscle of vascular endothelium which this effect is attributed to more release of prostaglandins than of nitric oxide (NO) from endothelium [57]. The mechanism of pharmacological action of $P$. oleracea on respiratory system were shown (Fig. 4).

\subsection{Quercetin}

It has been reported that quercetin inhibits the contraction caused by phenylephrine in aorta of rat [58] as well as the contraction induced by anaphylaxis in guinea pig ileum [59]. Quercetin inhibited smooth muscle cells proliferation, G1 cell-cycle arrest, decreased in the kinase activities, inhibit TNF-a induced induction of MMP-9 enzyme activity, decreasing the nuclear factor kappa B (NF-kB) binding activity in Human aortic smooth muscle cells [60]. Scientific evidence demonstrated that quercetin suppressed the high $\mathrm{KCl}$ - induced contractions and noradrenaline in rat isolated aorta [61]. The results of studies determined that quercetin inhibited smooth muscle cells proliferation and suppressed migration them from the media into intima [62]. In addition, quercetin (10-80 $\mu \mathrm{g} /$ $\mathrm{mL}$ ) inhibited the effect of TNF- $\bigotimes$ on DNA synthesis and ERK1/2 activation as well as inhibition of cyclin D1/CDK4 and cycline E/CDK2 activities in human aortic smooth muscle cells [60]. Quercetin has also been indicated to inhibit angiotensin II (Ang II) - induced C-Jun N- terminal kinase (JNK) activation in cultured rat aorta smooth muscle which this inhibitory effect may be attributed to its antioxidant effects [63]. The relaxant effects of quercetin includes by inhibition of $\mathrm{Ca}+2$ influx and release of $\mathrm{Ca}+2$ from intracellular stores [57]. Quercetin enhanced relaxation of rat aortic ring segments [64]. This results indicated that quercetin-mediated stimulation of eNOS phosphorylation increases NO bioavailability in endothelial cells. Oral administration of quercetin significantly reduced hyperreactivity of airways smooth muscle in Guinea pig [65]. Smooth muscle relaxant effects of P. oleracea and quercetin were showed in the Table 2 . 
Table 2 Smooth muscle relaxant effects of P. oleracea and quercetin

\begin{tabular}{|c|c|c|c|c|c|}
\hline Plants & Extract & $\begin{array}{l}\text { Effective } \\
\text { doses }\end{array}$ & $\begin{array}{l}\text { Model of } \\
\text { study }\end{array}$ & Effects & Ref. \\
\hline \multirow[t]{6}{*}{ P. Oleracea } & $\begin{array}{l}\text { Aqueous } \\
\text { extract }\end{array}$ & $0.25 \mathrm{mg} / \mathrm{kg}$ & $\begin{array}{l}\text { Asthmatic } \\
\text { patients }\end{array}$ & $\begin{array}{l}\text { Increased measured } \\
\text { PFTs }\end{array}$ & [46] \\
\hline & $\begin{array}{l}\text { Boiled and } \\
\text { aqueous } \\
\text { extracts }\end{array}$ & $\begin{array}{l}\text { Boiled } \\
(1.25 \mathrm{ml}) \\
\text { aqueous } \\
(6.25 \mathrm{ml})\end{array}$ & $\begin{array}{l}\text { Tracheal } \\
\text { chains of } \\
\text { guinea pig }\end{array}$ & $\begin{array}{l}\text { Relaxant effect on } \\
\text { tracheal chains }\end{array}$ & {$[66]$} \\
\hline & $\begin{array}{l}\text { Ethanolic } \\
\text { extract }\end{array}$ & $(250 \mu \mathrm{g} / \mathrm{ml})$ & Mice & $\begin{array}{l}\text { Reduced intestinal } \\
\text { motility }\end{array}$ & {$[55]$} \\
\hline & $\begin{array}{l}\text { Aqueous } \\
\text { extract }\end{array}$ & $600 \mu \mathrm{g} / \mathrm{ml}$ p.o. & $\begin{array}{l}\text { Isolated } \\
\text { guinea pig } \\
\text { ileum strip }\end{array}$ & Reduced pristaltic index & [47] \\
\hline & $\begin{array}{l}\text { Aqueous } \\
\text { extract }\end{array}$ & $7 \times 10^{-4} \mathrm{~g} / \mathrm{ml}$ & $\begin{array}{l}\text { Guinea pig } \\
\text { fundus, rabbit } \\
\text { jejunum and } \\
\text { rabbit aorta }\end{array}$ & $\begin{array}{l}\text { Relaxant effect on } \\
\text { smooth muscle and } \\
\text { reduced blood pressure }\end{array}$ & [48] \\
\hline & $\begin{array}{l}\text { Hydro- } \\
\text { ethanolic }\end{array}$ & & $\begin{array}{l}\text { Guinea pigs } \\
\text { tracheal } \\
\text { smooth } \\
\text { muscles }\end{array}$ & $\begin{array}{l}\text { Stimulatory effect on } \beta \text { - } \\
\text { adrenoceptor and } \\
\text { blocking of muscarinic } \\
\text { receptor }\end{array}$ & $\begin{array}{l}{[50,} \\
67]\end{array}$ \\
\hline \multirow{6}{*}{$\begin{array}{l}\text { Component } \\
\text { of } P \text {. } \\
\text { Oleracea }\end{array}$} & \multirow[t]{6}{*}{ Quercetin } & $10^{-4} \mathrm{~mol}$ & $\begin{array}{l}\text { Isolated rat } \\
\text { aorta }\end{array}$ & $\begin{array}{l}\text { Vasodilator effect on } \\
\text { Isolated rat aorta }\end{array}$ & [61] \\
\hline & & $10^{-5} \mathrm{~mol}$ & $\begin{array}{l}\text { Rat vascular } \\
\text { smooth } \\
\text { muscle }\end{array}$ & $\begin{array}{l}\text { Inhibitory effect on } \\
\text { phasic contractions }\end{array}$ & [68] \\
\hline & & $10-80 \mu \mathrm{g} / \mathrm{ml}$ & $\begin{array}{l}\text { Human aortic } \\
\text { smooth } \\
\text { muscle cells }\end{array}$ & $\begin{array}{l}\text { Inhibit smooth muscle } \\
\text { cells proliferation, } \\
\text { inhibited TNF-a induced } \\
\text { induction of MMP-9 } \\
\text { enzyme activity, } \\
\text { decreased the } \\
\text { NF-kB binding activity }\end{array}$ & [60] \\
\hline & & $0.3 \mathrm{~mm}$ & Rat aorta & Vasorelaxant response & [57] \\
\hline & & 5 and $10 \mu \mathrm{m}$ & $\begin{array}{l}\text { Rat thoracic } \\
\text { aortas }\end{array}$ & $\begin{array}{l}\text { Reduced vasoconstrictor } \\
\text { sensitivity in rat aortic } \\
\text { ring }\end{array}$ & [64] \\
\hline & & $20 \mathrm{mg} / \mathrm{kg}$ oral & Guinea pig & $\begin{array}{l}\text { Relaxed tracheal smooth } \\
\text { muscle }\end{array}$ & {$[65]$} \\
\hline
\end{tabular}

PFT: pulmonary function tests, NF-kB: nuclear factor kappa B, TNF- $\alpha$ : Tumor necrosis factor- $\alpha$, MMP- 9: Matrix Metalloprotienase-9. 


\section{Clinical evidences}

Therapeutic effects of P. oleracea in the airway of asthmatic patients showed that the oral admonition of $5 \%$ boiled extract $(0.25 \mathrm{ml} / \mathrm{kg})$ increased pulmonary function tests similar to theophylline [46]. Quercetin $(0.5,1,10,25$, $50 \mu \mathrm{M}$ ) significantly induced the gene expression of IFN- $\gamma$ and down regulated IL-4 in normal human peripheral blood mononuclear cell (PBMC). Additionally, treatment with quercetin increased the phenotypic expression of IFN- $\gamma$ cells and decreased IL- 4 in positive cells [42].

Quercetin $(5,10,25,50,100,200 \mu \mathrm{M})$ by itself and in combination with human IFN- $\beta(50 \mu \mathrm{M}+$ IFN- $\beta)$, in PBMC isolated from multiple sclerosis (MS) patients and from normal healthy subjects has been demonstrated to reduce the proliferation of PBMC and to modulate the level of IL- $1 \beta$ and TNF- $\alpha$. The combination of quercetin with IFN- $\beta$, showed additive effects in modulating TNF- $\alpha$ and MMP-9. Furthermore, quercetin reduced the MMP-9/ tissue inhibitor of metalloproteinases-1 (TIMP-1) ratio via lowering MMP-9 production in a dose-dependent manner. These effects of quercetin were similar between MS patients and healthy control subjects [43].

Oral administration of quercetin ( $1500 \mathrm{mg} /$ day) in rheumatoid arthritis patients significantly reduced IL-6, C3 and C4 levels and elevated IL-10 level in treated group with quercetin plus $100 \mathrm{mg}$ azathioprine, compared to treated group with azathioprine + placebo eight weeks after treatment [44].

\section{Conclusion}

Asthma disease is characterized by airway inflammation and smooth muscle dysfunction. P. oleracea and quercetin reduced the production of $\mathrm{NO}$, inflammatory cytokines and chemokines such as; IL-4, IL-1 $\beta$, TNF- $\alpha$, MMP-9 and TIMP-1. They also increased anti-inflammatory cytokines such as, IFN- $\gamma$ and IL-10 in in vivo and in vitro studies. This plant and its component has also been shown to have relaxant effects on tracheal smooth muscle by stimulatory effects on $\beta$-adrenoceptor as well as inhibitory effects on muscarinic receptors in tracheal smooth muscles. The results of this review articles indicated P. oleracea and its constituents particularly quercetin have anti-inflammatory and smooth muscle relaxant effects and potential therapeutic effects on allergic asthma.

\section{References}

1. Bousquet J, Jeffery PK, Busse WW, Johnson M, Vignola AM. Asthma: from bronchoconstriction to airways inflammation and remodeling. Am j resp crit care med. 2000;161(5):1720-45.

2. Anderson GP, Coyle AJ. TH2 and 'TH2-like'cells in allergy and asthma: pharmacological perspectives. Trends pharm sci. 1994;15(9):324-32.

3. Hoogsteden H, Verhoeven G, Lambrecht B, Prins JB. Airway inflammation in asthma and chronic obstructive pulmonary disease with special emphasis on the antigen presenting dendritic cell: influence of treatment with fluticasone propionate. Clin Exp All. 1999;29:116-24.

4. Janssen LJ, Killian K. Airway smooth muscle as a target of asthma therapy: history and new directions. Resp res. 2006;7(1):123.

5. Barnes PJ. Corticosteroids: the drugs to beat. Eur $j$ pharmacol. 2006;533(1-3):2-14.

6. Sears MR, Taylor DR, Lake D, Li Q, Flannery E, Yates D, et al. Regular inhaled beta-agonist treatment in bronchial asthma. The Lancet. 1990;336(8728):1391-96.

7. Khazdair M, Boskabady M, Tabatabaee A, Hosseini M, Abbasnejad M. Effect of inhaled fluticasone and salmeterol on tracheal responsiveness and lung inflammation: influence of administration time and allergen-free period. India j med sci. 2013;67(3/4):78.

8. Gholamnezhad Z, Boskabady MH, Khazdair MR, Hosseini M, Abbasnejad M. Effect of fluticasone and salmeterol on tracheal responsiveness to ovalbumin and lung inflammation, administrated during and after sensitization. Sci World J. 2014;2014.

9. Greenberger PA, editor Therapy in the management of the rhinitis/asthma complex. Allergy and asthma proceedings; 2003: OceanSide Publications, Inc.

10. Zargari A. Medicinal plants: Tehrari University Publications. ISBN; 1995.

11. Martins WB, Rodrigues SA, Silva HK, Dantas CG, JÚ NIOR WDL, Cardoso JC, et al. Neuroprotective effect of Portulaca oleracea extracts against 6-hydroxydopamine-induced lesion of dopaminergic neurons. Anai da Acad Brasil de Ciências. 2016;88(3):1439-50.

12. Eidi A, Mortazavi P, Moghadam JZ, Mardani PM. Hepatoprotective effects of Portulaca oleracea extract against CCl4-induced damage in rats. Pharm biol. 2015;53(7):1042-51.

13. Lim Y, Quah E. Antioxidant properties of different cultivars of Portulaca oleracea. Food chem. 2007;103(3):73440.

14. Hwang JT, Kim Y, Jang H-J, Oh H-M, Lim C-H, Lee SW, et al. Study of the UV Light Conversion of Feruloyl Amides from Portulaca oleracea and Their Inhibitory Effect on IL-6-Induced STAT3 Activation. Molecules. 2016;21(7):865.

15. Askari VR, Rezaee SA, Abnous K, Iranshahi M, Boskabady MH. The influence of hydro-ethanolic extract of Portulaca oleracea L. on Th1/Th2 balance in isolated human lymphocytes. J ethnopharmacol. 2016;194:1112-21. 
16. Simopoulos AP. Omega-3 fatty acids and antioxidants in edible wild plants. Biol Res.2004;37(2):263-77.

17. Choudhary C, Meruva A, Ranjith N, Elumalai K. A Review of Phytochemical and Pharmacological Profile of Portulaca oleracea Linn. Int J Res Ayur Pharm. 2013;4(1):34- 37.

18. Zhou Y-X, Xin H-L, Rahman K, Wang S-J, Peng C, Zhang H. Portulaca oleracea L.: a review of phytochemistry and pharmacological effects. BioMed res int. 2015;2015.

19. Askari VR, Rezaee SA, Abnous K, Iranshahi M, Boskabady MH. The influence of hydro- ethanolic extract of Portulaca oleracea L. on Th 1/Th 2 balance in isolated human lymphocytes. J Ethnopharmacol. 2016.

20. Lee AS, Kim JS, Lee YJ, Kang DG, Lee HS. Anti-TNF- $₫$ activity of Portulaca oleracea in vascular endothelial cells. Int j mol sci. 2012;13(5):5628-44.

21. Seo S-W. The anti-inflammatory effect of Portulaca oleracea $70 \%$ EtOH Extracts on lipopolysaccharide-induced inflammatory response in RAW 264.7 cells. Korea J Herbol. 2015;30(6):33-38.

22. Zhao R, Zhang T, Zhao H, Cai Y. Effects of Portulaca oleracea L. polysaccharides on phenotypic and functional maturation of murine bone marrow derived dendritic cells. Nut cancer. 2015;67(6):987-93.

23. YouGuo C, ZongJi S, XiaoPing C. Evaluation of free radicals scavenging and immunity- modulatory activities of Purslane polysaccharides. Int j biol macromol. 2009;45(5):448-52.

24. KE L-s, GUO J-z, YANG J-y, MA S-x. The immunomodulatory effect of the Polysaccharides of Portulaca Oleracea on senescence mice [J]. Heilongjiang Med Pharm. 2012;2:014.

25. Chen B, Zhou H, Zhao W, Zhou W, Yuan Q, Yang G. Effects of aqueous extract of Portulaca oleracea L. on oxidative stress and liver, spleen leptin, PAR区 and FAS mRNA expression in high-fat diet induced mice. Mol biol rep. 2012;39(8):7981-88.

26. Arruda SF, Siqueira EM, Souza EM. Malanga (Xanthosoma sagittifolium) and purslane (Portulaca oleracea) leaves reduce oxidative stress in vitamin A-deficient rats. Ann nut metabol. 2004;48(4):288-95.

27. Kaveh M, Eidi A, Nemati A, Boskabady MH. The extract of portulaca oleracea and its constituent, Alpha linolenic acid affects serum oxidant levels and inflammatory cells in sensitized rats. Iranian J All Asth Immunol. 2017;16(3):256-70.

28. Sharma A, Vijayakumar M, Rao CV, Unnikrishnan M, Reddy G. Action of Portulaca oleracea against streptozotocin-induced oxidative stress in experimental diabetic rats. J Complement Integ Med. 2009;6(1).

29. Yue T, Xiaosa W, Ruirui Q, Wencai S, Hailiang X, Min L. The effects of Portulaca oleracea on hypoxia-induced pulmonary edema in mice. High altitude med biol. 2015;16(1):43-51.

30. Dkhil MA, Moniem AEA, Al-Quraishy S, Saleh RA. Antioxidant effect of purslane(Portulaca oleracea) and its mechanism of action. J Med Plant Res. 2011;5(9):1589-93.

31. Huang R-Y, Yu Y-L, Cheng W-C, OuYang C-N, Fu E, Chu $\mathrm{C}$-L. Immunosuppressive effect of quercetin on dendritic cell activation and function. J Immunol. 2010;184(12):681521.
32. Yu ES, Min HJ, An SY, Won HY, Hong JH, Hwang ES. Regulatory mechanisms of IL-2 and IFN $\gamma$ suppression by quercetin in T helper cells. Bioch pharmacol. 2008;76(1):70-78.

33. Comalada M, Camuesco D, Sierra S, Ballester I, Xaus J, Gálvez J, et al. In vivo quercitrin anti inflammatory effect involves release of quercetin, which inhibits inflammation through down regulation of the NFxB pathway. Eur j immunol. 2005;35(2):584-92.

34. Park H-j, Lee C-M, Jung ID, Lee JS, Jeong Y-i, Chang $\mathrm{JH}$, et al. Quercetin regulates Th1/Th2 balance in a murine model of asthma. Int immunopharmacol. 2009;9(3):261-67.

35. Liu L, Howe P, Zhou Y-F, Xu Z-Q, Hocart C, Zhang R. Fatty acids and $\beta$-carotene in Australian purslane (Portulaca oleracea) varieties. J chromatograph A. 2000;893(1):207-13.

36. Kelley DS, Branch LB, Love JE, Taylor PC, Rivera YM, Iacono J. Dietary $\alpha$-linolenic acid and immunocompetence in humans. Am j clin nut. 1991;53(1):40-46.

37. Arm JP, Horton CE, Spur BW, Mencia-Huerta J-M, Lee TH. The effects of dietary supplementation with fish oil lipids on the airways response to inhaled allergen in bronchial asthma. Am J Resp Crit Care Med. 1989;139(6):1395-400.

38. Yue ME, Jiang TF, Shi YP. Simultaneous determination of noradrenaline and dopamine in Portulaca oleracea L. by capillary zone electrophoresis. J sep sci. 2005;28(4):360-64.

39. Elkhayat ES, Ibrahim SR, Aziz MA. Portulene, a new diterpene from Portulaca oleracea L. J Asia nat prod res. 2008;10(11):1039-43.

40. Uddin M, Juraimi AS, Hossain MS, Un A, Ali M, Rahman M. Purslane weed (Portulaca oleracea): a prospective plant source of nutrition, omega-3 fatty acid, and antioxidant attributes. Sci World J. 2014;2014.

41. Palaniswamy UR, Bible BB, McAvoy RJ. Effect of nitrate: ammonium nitrogen ratio on oxalate levels of purslane. Trends in new crops and new uses. 2002;11(5):453-55.

42. Nair MP, Kandaswami C, Mahajan S, Chadha KC, Chawda R, Nair H, et al. The flavonoid, quercetin, differentially regulates Th-1 (IFN $\gamma$ ) and Th-2 (IL4) cytokine gene expression by normal peripheral blood mononuclear cells. Biochim Biophys Acta (BBA)-Mol Cell Res. 2002;1593(1):29-36.

43. Sternberg Z, Chadha K, Lieberman A, Hojnacki D, Drake A, Zamboni P, et al. Quercetin and interferon- $\bigotimes$ modulate immune response (s) in peripheral blood mononuclear cells isolated from multiple sclerosis patients. J neuroimmunol. 2008;205(1):142-47.

44. Al-Rekabi MD, Ali SH, Al-Basaisi H, Hashim F, Hussein $\mathrm{AH}$, Abbas HK. Immunomodulatory Effects of Quercetin in Patient with Active Rheumatoid Arthritis. Br J Med Health Res. 2015;2(6):23-34.

45. Okwuasaba F, Ejike C, Parry O. Comparison of the skeletal muscle relaxant properties of Portulaca oleracea extracts with dantrolene sodium and methoxyverapamil. J ethnopharmacol. 1987;20(2):85-106.

46. Malek F, Boskabady M, Borushaki M, Tohidi M. Bronchodilatory effect of Portulaca oleracea in airways of asthmatic patients. J ethnopharmacol. 2004;93(1):57-62. 
47. Oluwol F, Oyediji K. Calcium ions influences smooth muscle relaxant response to aqueous extract of Portulaca oleracea. J Med Sci. 2007;7(2):238-42.

48. Parry O, Okwuasaba F, Ejike C. Effect of an aque-

48. ous extract of Portulaca oleracea leaves on smooth muscle and rat blood pressure. J ethnopharmacol. 1988;22(1):33-44.

49. Boskabady MH, Hashemzehi M, Khazdair MR, Askari VR. Hydro-ethanolic Extract of Portulaca oleracea Affects Beta-adrenoceptors of Guinea Pig Tracheal Smooth Muscle (Autumn 2016). Iran J Pharm Res. 2016.

50. Hashemzehi M, Khazdair M, Kiyanmehr M, Askari V, Boskabady M. Portulaca olerace Affects Muscarinic Receptors of Guinea Pig Tracheal Smooth Muscle. India J Pharm Sci. 2016;78(3):388-94.

51. Martin C, Naline E, Bakdach H, Advenier C. Beta 3-adrenoceptor agonists, BRL 37344 and SR 58611A, do not induce relaxation of human, sheep and guinea-pig airway smooth muscle in vitro. Eur Res J. 1994;7(9):1610-15.

52. Buckle D, Arch J, Bowring N, Foster K, Taylor J, Taylor S, et al. Relaxant effects of the potassium channel activators BRL 38227 and pinacidil on guinea-pig and human airway smooth muscle, and blockade of their effects by glibenclamide and BRL 31660. Pulmon pharmacol. 1993;6(1):77-86.

53. Van Amsterdam RG, Meurs H, Brouwer F, Postema JB, Timmermans A, Zaagsma J. Role of phosphoinositide metabolism in functional antagonism of airway smooth muscle contraction by $\bigotimes$-adrenoceptor agonists. European Journal of Pharmacology: Mol Pharmacol. 1989;172(2):175-83.

54. Miyahara Y, Kizawa Y, Sano M, Murakami H. Effects of organic and inorganic $\mathrm{Ca}(2+)$ - antagonists on acetylcholine-induced contraction in molluscan (Mytilus edulis) smooth muscle. General pharmacol. 1993;24(6):1419-23.

55. Catap ES, Kho MJL, Jimenez MRR. In vivo nonspecific immunomodulatory and antispasmodic effects of common purslane (Portulaca oleracea Linn.) leaf extracts in ICR mice. J ethnopharmacol. 2018;215:191-98.

56. Lee AS, Lee YJ, Lee SM, Yoon JJ, Kim JS, Kang DG, et al. Portulaca oleracea ameliorates diabetic vascular inflammation and endothelial dysfunction in $\mathrm{db} / \mathrm{db}$ mice. Evid-Bas Complement Alternat Med. 2012;2012.

57. Ajay M, Gilani A-uH, Mustafa MR. Effects of flavonoids on vascular smooth muscle of the isolated rat thoracic aorta. Life Sci. 2003;74(5):603-12.

58. Beretz A, Anton R, Stoclet J. Flavonoid compounds are potent inhibitors of cyclic AMP phosphodiesterase. Experientia. 1978;34(8):1054-55.

59. Fanning MJ, Macander P, Drzewiecki G, Middleton Jr E. Quercetin inhibits anaphylactic contraction of guinea pig ileum smooth muscle. Int Arch All Immunol. 1983;71(4):371-73.

60. Moon S-K, Cho G-O, Jung S-Y, Gal S-W, Kwon TK, Lee Y-C, et al. Quercetin exerts multiple inhibitory effects on vascular smooth muscle cells: role of ERK1/2, cell-cycle regulation, and matrix metalloproteinase- 9 . Biochem biophys res commun. 2003;301(4):1069-78.

61. Duarte J, Pérez-Vizcaíno F, Zarzuelo A, Jiménez J, Tama- rgo J. Vasodilator effects of quercetin in isolated rat vascular smooth muscle. Eur j pharmacol. 1993;239(13):1-7.

62. Alcocer F, Whitley D, Salazar-Gonzalez JF, Jordan WD, Sellers MT, Eckhoff DE, et al. Quercetin inhibits human vascular smooth muscle cell proliferation and migration. Surgery. 2002;131(2):198-204.

63. Yoshizumi M, Tsuchiya K, Kirima K, Kyaw M, Suzaki Y, Tamaki T. Quercetin inhibits Shc-and phosphatidylinositol 3-kinase-mediated c-Jun N-terminal kinase activation by angiotensin II in cultured rat aortic smooth muscle cells. Mol Pharmacol. 2001;60(4):656- 65.

64. Khoo NK, White CR, Pozzo-Miller L, Zhou F, Constance $\mathrm{C}$, Inoue T, et al. Dietary flavonoid quercetin stimulates vasorelaxation in aortic vessels. Free Radical Biol Med. 2010;49(3):339-47.

65. Joskova M, Franova S, Sadlonova V. Acute bronchodilator effect of quercetin in experimental allergic asthma. Bratisl Lek Listy. 2011;112(1):9-12.

66. Boskabady M, Broshaki M, Aslani M, Malek F. Possible mechnisms of relaxant effect of Portulaca oleraceae on tracheal chains of guinea pig. Iran J Pharm Res. 2010:51-51.

67. Boskabady MH, Hashemzehi M, Khazdair MR, Askari VR. Hydro-ethanolic Extract of Portulaca oleracea Affects Beta-adrenoceptors of Guinea Pig Tracheal Smooth Muscle. Iran j pharm res: IJPR. 2016;15(4):867.

68. Duarte J, Pérez-Vizcaíno F, Zarzuelo A, Jiménez J, Tamargo J. Inhibitory effects of quercetin and staurosporine on phasic contractions in rat vascular smooth muscle. Eur j pharmacol. 1994;262(1-2):149-56. 